\title{
Empowerment Zones and Enterprise Communities: Moving from Legislative Concept to Successful Implementation
}

\author{
The Honorable Henry G. Cisneros
}

Henry G. Cisneros, Housing and Urban Development Secretary, received his Doctor of Public Administration from The George Washington University in 1976. Prior to his cabinet position in the Clinton administration, Secretary Cisneros served as mayor of San Antonio, Texas, deputy chairman of the Federal Reserve Bank of Dallas, chairman of the National Civic League and a member of the board of the Rockefeller Foundation.

The plenary address by the Hon. Henry G. Cisneros, Secretary of the Department of Housing and Urban Development, at the conference: "Empowerment Zones and Enterprise Communities: Moving from Legislative Concept to Successful Implementation" at The Geonge Wasbington University, November 18-19, 1993.

Thank you for giving me the opportunity to be one of the presenters at this conference on Empowerment Zones, an important idea that has been discussed for better than a decade now but is coming to reality because President Clinton has believed in it and included it in the first year's legislative program of the Administration. It's a special treat to be at The George Washington University. It's my first opportunity to be here since joining the Administration, after years of walking these halls as a student, and later being here in other capacities, but never in this role. There's a special nostalgia to the moment because I have said on many occasions that I owe many of my skills that allowed me to serve as the mayor of San Antonio to what I learned in the Public Administration program here at George Washington.

I think it's important for universities to establish a relationship to the larger causes of our time. It's important to the students, it's important to the professors, it's important to the university to advance the state of the art in knowledge and assemble people who can manage the art of the practice of politics and public administration. I think it's a particularly important contribution that The George Washington University would strive to understand Empowerment Zones and urban problems in Washington, D.C., for several reasons.

First, as we know, Washington is a city that has many urban difficulties. Second, it is a city to which the nation looks, so what happens here in Washington gets an extremely high profile in the country at large. Third, because the Congress is here, when urban solutions fail in
Washington they are viewed as an indicator that they cannot work anywhere else. So, Washington, D.C., as a community, cries for a relationship with every major institution in its physical boundaries that can be a positive force.

Washington, D.C., is handicapped by having such a different relationship with the Congress that some of [the government's] institutions don't take [Washington, D.C.] seriously as a city. Those institutions would behave differently if this were New York or Cleveland or Los Angeles or another place where they gave their total well-being to the community, where they saw their fate and future and destiny as totally linked to the metropolitan area. Washington institutions haven't always played that role, but under President Trachtenberg, The George Washington University has begun to try to make that kind of commitment. I think today's conference is an indication of it, and I want to applaud your leadership in that area.

\begin{tabular}{c} 
"I think it's important for universities \\
to establish a relationship to the \\
larger causes of our time... \\
to advance the state of the art in \\
knowledge and assemble people who \\
can manage the art of the practice of \\
politics and public administration." \\
\hline \hline
\end{tabular}

The timing of this conference couldn't be better. We're just beginning to implement the $\$ 3.5$ billion Empowerment Zones and Enterprise Community program which was proposed by President Clinton last Spring and approved by Congress this Summer. Empowerment Zones and Enterprise Communities are urgently needed in our cities. 
They can help combat the crime, unemployment and fear which permeates urban America. Our nation must focus on the problems tearing our urban and rural communities apart and restore hope to our fellow citizens. President Clinton understands this and he's committed to revitalizing our cities and solving urban problems largely ignored for the past decade. Because our nation lacked a focused urban strategy that addressed community needs and encouraged economic opportunity, empowerment zones are a larger part of President Clinton's urban policy agenda.

\section{"Our nation must focus on the problems tearing our urban and rural communities apart and restore bope to our fellow citizens."}

Now some have criticized the President for not offering an urban agenda - a cohesive, coherent strategy of urban initiatives. But when one looks at the record of the last year one can only conclude that what is emerging is as sound an urban strategy as any administration has ever had. When you look at what the President has already done in the first year, its a very impressive urban agenda. It includes many of the things that many of us have been calling for in bits and pieces over the years. For example, the Eamed Income Tax Credit that was passed with the recent economic plan promises to eliminate that class of Americans who we call the "working poor," people who work full time, 40 hours a week and still are below the poverty level. With the Earned Income Tax Credit, they receive a tax rebate which enables them to rise above the poverty line. The permanent extension of mortgage revenue bonds makes it possible for state housing finance agencies to bring millions, billions of dollars to housing that otherwise would not have been possible. The permanent extension of low-income tax credits, also passed in this economic plan, already is drawing hundreds of million of dollars to intermediary groups such as LISC and Enterprise so that they can build affordable housing in the central cities.

Other accomplishments include the following;

- The request for the full funding of Head Start;

- The inauguration of a massive immunization program that reaches central-city children, a large percentage of whom go unimmunized in our society;
- The passage of National Service which will bring young talent to the cities and our communities, bringing the same energies on a scale, and with a long-term legacy, which I think equals what the Peace Corps represented in the 1960s;

- The commitment to strengthen the Community Reinvestment Act so credit is redirected on the part of commercial institutions back to central city areas;

- The commitment on the part of the Department of Iabor to focus on training and retraining with a special emphasis on grouping the differentiated training programs so that they make a coherent whole in our urban areas.

All of these are examples of what has already been done. When one adds that to the promise of what lies ahead, the promise of welfare reform, which will do more to touch the.lives of the poor and match their prospects to training and introduce the notion of self sufficiency over time with strong governmental assistance, that is a very powerful urban program. Add to that the commitment to put in place community development banks, and perhaps the underpinning of security for most Americans - national health care reform - which will guarantee that Americans will receive a comprehensive health care package that will never be taken away. And those 37 million of our citizens who are uninsured are largely central city residents who today have no altemative but to throw themselves on the mercy of trauma care units and emergency units even when it involves flu for a child because there is no alternative in many central city areas.

This represents a litany, a listing of important urban programs that many of you have chronicled, watched, observed, called for, and demanded over the years. These programs are also beginning to be organized in a strategy of assaulting the pressing problems confronting America. From education and training issues to health and children's questions, to Head Start and immunization issues, to credit and banking questions, to housing and redevelopment strategies, a confluence of important streams of urban and rural development thinking is emerging. At HUD our priorities underscore the President's efforts, and we have five priorities at HUD:

First, to reduce homelessness, because it is clear that those Americans who are suffering most among our fellow citizens are those who sleep on cold city sidewalks at night. As a Department whose title begins with housing, we have an obligation first and foremost to those who are completely unhoused. It's a sad thing to walk around this neighbor 
hood at this University, to the stairs of the Federal Reserve Bank where I saw one night a lady with horrible sores on her legs, sleeping on the stairway of the nation's symbol of its wealth, the Federal Reserve System. A first priority must be to deal with homelessness, and once again we've selected the District of Columbia for a special relationship for the reasons that I cited earlier. It is a signal to the country whether these problems can be seriously addressed or not. And if we can't address them in our backyard with the Congress in full view, what chance do we have to gain full support for these initiatives across the country?

Second, we're committed to improving the worst conditions in public housing. We must change not only the funding strategies that have allowed the money to be used ineffectively, but the very dynamics of public housing rules and regulations as well.

Third, we're committed to a strategy of large-scale production of affordable housing and, very importantly, of home ownership. For the first time in modern American history, the number of American home owners has declined, from a high in 1980. And it is no accident that it parallels the demise of one of HUD's important public policy institutions, FHA, which has been denigrated consistently over the last decade.

Fourth, HUD is committed to a strategy of open housing to assure that Americans have choice no matter what their color or class or income; that there be the possibility of making real choices of moving from concentrated areas of minority and low-income populations to other settings; that the barriers of exclusivity, of zoning, and so forth, are not so strict that we differentiate Americans and concentrate Americans and deepen the chasm of segregation in our society.

And finally, we're committed to investing in communities through the institutions, through focusing on the network of community-based energy that exists across America in cooperation with state and local government. But this is a different strategy from the federal government being the entity that hands down recipe-book solutions, already cooked solutions. Instead, we focus on a new era of collaboration, reinventing government not just internally within the federal structure, but, more profoundly, within the relationship between federal institutions and communities.

This brings me to Empowerment Zones (of which there are six in big cities and three in rural areas), and 95 Enterprise Communities, an essential part of the President's comprehensive urban national revitalization strategy.
The Empowerment Zone approach combines tax incentives, public investment, and relief from regulations to generate strong economic growth and development all across the country. The needs of local communities will be met through an integrated approach that combines private-sector innovation with responsible state and local government support. The Empowerment legislation passed by Congress provides $\$ 1$ billion in social services to the Empowerment and Enterprise communities and $\$ 2.5$ billion in tax incentives. What this means, simply stated, is that the communities which are selected will be selected for particular zones, and that, within those zones, substantial credits will be available to employers who employ people who either live in, or create jobs within, the Empowerment Zone area. That's never been tried by the federal government. It has been tried with mixed success at state and local levels, but it never had the full power of federal tax incentives and certainly not collaboration with the federal agencies. I think this approach is going to be even more attractive than the tax incentives, in fact.

\begin{tabular}{c}
\hline \hline "We focus on a new era of \\
collaboration, reinventing \\
government not just internally \\
within the federal structure, \\
but, more profoundly, within the \\
relationship between federal \\
institutions and communities." \\
\hline \hline
\end{tabular}

To demonstrate his commitment to the initiative, the President has established a very important body within the government. President Clinton established the Community Enterprise Board which will be chaired by the Vice-President - a very focused, intelligent, directed person. The Community Enterprise Board will have two vice chairs. One of them is Bob Rubin, the Chair of the National Economic Policy Council, the person who organizes the thoughts and paperwork going into the President on the economy. The other Vice Chair will be Carol Rasco, the Chair of the Domestic Policy Council, the person who is most involved with welfare reform and working with the First Iady on health care reform. So the human services agenda is integrated into this thinking about urban strategy. The members of the task force are all from the domestic cabinet agencies. 
This Board will have three responsibilities. First, it will design, select, and oversee the Empowerment Zone and Enterprise Communities initiative.

The second task will be to look, apart from the Enterprise Zones and Empowerment Zones, at the things that cabinet agencies can be doing collaboratively in Washington, and to obtain the maximum community benefit from relief of regulations, the granting of waivers, and the infusion of flexibility. And third, the Vice-President has in mind selecting places where we can demonstrate our ability to collaborate in place-oriented strategy, apart from the Enterprise Zones and Empowerment Zones - places where it can just make sense for us to start from the bottom up, and relate to what a community is already doing, and make the federal government not the creator of change, but respond to the demands of change from communities.

Now to the Zones themselves. The President has sent a strong signal to the American people that he wants change, and Empowerment Zones will bring full resources to bear in communities that are trying to mirror that change on the local level. We're working with other Federal departments now to find the inter-agency solutions that will cross lines, and build them into the Empowerment Zones concept. The Vice-President has cancelled appointments for entire mornings over the last month, on five or six occasions, to hear from experts in community organizations, experts in community credit, experts in local government, experts in the relations between community and crime fighting, and experts in the relations between communities and educational strategies, in order to build the most relevant state-ofthe-art themes into the application requests that go out.

The basis for the designation as an Enterprise Zone or Empowerment Community will be to strengthen the quality of the strategic plan that is offered in the application. Applicants must submit a plan that coordinates economic, human, community and physical development for approved areas. We'll look for plans that link social problems with job training so that low-income people have the opportunity to lift themselves out of poverty. Designating the Zones and Communities will not be an easy task because I know that many communities will submit outstanding strategic plans that will become outstanding national models in the future.

While I know all of you will try to seek the six large urban zones or the three large rural zones, obviously there will be only nine selected from across the country, Which means 95 other communities will be working with the Enterprise Community designations or neighborhood designations. Let me tell you, I think those are going to be very powerful. They ought not be viewed as a consolation prize, because I think that the kind of federal resources that we will be able to bring together in those communities may well be the real prize here. My own experience, as a mayor whose first commitment was economic development for the first four years of my eight-year term, tells me that the principal attraction was the coordination of the governmental activities.

So, what I'm saying is when you're designated, as some of you will be, in Enterprise Communities, this is a significant thing to work on. Pick neighborhoods that you think can really benefit from bringing together the Justice Department and weed and seed programs; the Department of Education and Head Start and school improvements and magnet school investments; HUD and housing redevelopment and retail community investment; Commerce and small business investment; Small Business Administration and small business strategies; the EPA and toxic site and Superfund investing; HHS and health clinics and health initiatives and child care programs. It's a pretty powerful array of resources that can be focused in a community setting. I think it is a major starting point to work from a neighborhood base up. $\star$ 
